УДК 94 (81) «1985/1995»

DOI: https://doi.org/10.33782/eminak2019.3(27).323

\title{
ФОРМУВАННЯ ЗОВНІШНЬОЇ ПОЛІТИКИ БРАЗИЛІЇ З 1985 ПО 1995 РОКИ: ВІД ЖОЗЕ САРНІ ДО ІТАМАРА ФРАНКО
}

\author{
Мирослав Жога \\ Державна установа «Інститут всесвітньої історії» НАН України» (Київ, Україна) \\ e-mail: miroslavzhoga@gmail.com \\ ORCID: https://orcid.org/0000-0002-4049-9411
}

у даній статті здійснена спроба аналізу зовнішньої політики Бразилії з 1985 по 1995 рр. Особливу увагу приділено місцю президентів Бразилії та їхньому впливу на розвиток зовнішньої політики країни. Проведено аналіз факторів, що вплинули на формування зовнішньої політики Бразилії у відносинах з США, ЄС та країнами Латинської Америки, визначено характер їх змін упродовж означеного періоду.

Ключові слова: Бразилія, зовнішня політика, Латинська Америка, автономія, МЕРКУСОР

Розпад двополярної системи призвів до появи нових центрів регіонального впливу та створення багатополярної системи міжнародних відносин. Актуальність даної проблематики багато у чому обумовлена винятковим характером бразильської зовнішньої політики, яка протягом періоду військової диктатури та періоду демократизації неодноразово змінювалась і трансформувалась, демонструючи різний характер власної політики від практично повної автономії від усього світу до регіонального лідера на світовій арені. Незважаючи на певну долю скептицизму, Бразилія сприймається світовою громадськістю, як нова сила західної півкулі, що здатна бути лідером Латинської Америки. Варто зазначити також роль і місце, яке вона посідала у політиці бразильських президентів.

Дана проблематика не є достатньо дослідженою та висвітленою у вітчизняній історичній науці, тому ми у нашому дослідженні переважно користувались роботами бразильських та американських авторів з цієї теми. Багато з них присвячені загальним питанням, а деякі торкаються переважно моментів періоду формування зовнішньополітичного курсу. Більшу частину таких досліджень складають роботи бразильських істориків: Борис Фаусто, Марія Реджіна Соареш де Ліма, Кармен Фонсека, Міріам Гомеш Сарайва, Тулло Віжевані, Пауло Візентіні. Окрему групу досліджень складають роботи, що стосуються переважно теорії зовнішньої політики Бразилії. Серед них хотілося б відзначити публікації Габріеля Чепалуні, Тулло Віжевані та Філіпа С. Шміттера, Роберто Рассела та Хуана Габріеля Токатляна, а також Моніки Хірст і Летісії Піньейру. Попри на наявність досить значної кількості публікацій, все ж робіт присвячених зовнішній політиці Бразилії з 1985 по 1995 роки, вкрай мало.

Мета нашого дослідження у рамках даної публікації полягає у спробі визначити особливості, які впливали на зовнішню політику Бразилії у зазначений період, виокремити основні пріоритети зовнішньої політики країни періоду відходу від військової диктатури з 1985 р. і до початку XXI ст., що проходили у тісному зв'язку з внутрішніми змінами, які переживала країна.

Саме тому основними завданнями нашого дослідження пропонується визначити основні лінії спадковості та характер зовнішніх і внутрішніх перетворень, які відбу- 
вались у Бразилії на той час, при цьому приділяючи особливу увагу головним напрямкам зовнішньої політики.

У роботі використано низку загальнонаукових методів досліджень, таких як історико-логічний, метод системного аналізу, структурно-функціональний підхід, індуктивно-логічний метод і метод порівняння. Хронологічні рамки статті стосуються періоду 1985-1995 рр. й охоплюють такі етапи формування зовнішньої політики урядів наступних президентів Бразилії: Жозе Сарні (1985-1990), Фернандо Коллора ді Меллу (1990-1992), Ітамара Франку (1992-1995). У свою чергу, дані етапи нами були поділені на три наступні періоди: 1) період демократичних перетворень, що відповідає політиці уряду Жозе Сарні, в якому іноземні стратегії Бразилії значною мірою залежать від внутрішніх умов; 2) період кризи «перехідного періоду», який був притаманний урядам Коллора ді Меллу та Ітамара Франку, що виникли внаслідок внутрішніх негараздів і негативної економічної ситуації у країні.

3 початком відновлення демократії в Бразилії у 1985 р., її традиційні принципи та напрямки зовнішньої політики базувались на наступних засадах: 1) повага до суверенітету інших держав і міжнародного права, 2) пацифізм та універсалізм. Проте у період військової диктатури (1964-1984 рр.) ${ }^{1}$ у бразильській зовнішній політиці сформувалася своя особиста стратегія ведення міжнародних відносин, яка переважно базувалася на принципі невтручання у справи інших держав, при цьому маючи залежність від впливу Сполучених Штатів Америки². Ця політика бразильських урядів отримала назву «відповідальний прагматизм», який, у свою чергу, був впроваджений за часів уряду президента Ернесто Гейзеля та формувався за його міністра закордонних справ Азередо да Сілвейри у 70-ті роки ХX ст.

Принцип «Відповідального прагматизму» був спрямований на задоволення економічних потреб, які були пов'язані зі стратегією зовнішньої політики, направленої на автономію від великих держав. Бразильська автономія визначала міжнародну політику країни. Цю стратегію можна поділити на три типи: 1) автономія через дистанцію; 2) автономія через участь; 3) автономію через диверсифікацію. Перший тип автономії притаманний періоду військової диктатури, другий і третій періоди автономії притаманні періоду демократизації й особливостям зовнішньої політики Бразилії цього періодуз3.

Саме поняття автономії краще зрозуміти з точки зору національних інтересів держави. В основу цих національних інтересів неформально узагальнюють такі поняття як життя, майно та свобода. Однак при цьому ці три національні інтереси можуть бути конфліктними, наприклад, деякі держави готові зменшити рівень свободи на користь більшого економічного процвітання або безпеки. Так, зокрема, спеціалісти зі зовнішньої політики Роберто Рассел і Хуан Габріель Токатлян ${ }^{4}$ дійшли висновку, що концепцію суверенітету варто використовувати лише в юридичній термінології. Вони вважають за потрібне використовувати поняття автономії лише з точки зору реального стану залежності або об’єктивного національного інтересу країни.

Після того, як протягом 1984 р. у Бразилії пройшли масові демонстрації, на яких

\footnotetext{
1 Період у бразильській історії з 1964 по 1984 р., коли при владі були військові.

2 Fausto B. História do Brasil. Vol. 1. São Paulo: Edusp, 1994. 653 p.

3 Vigevani T., Cepaluni G., Schmitter Ph.C. Brazilian Foreign Policy in Changing Times: The Quest for Autonomy from Sarney to Lula. Maryland: Lexington Books, 2009. $190 \mathrm{p}$.

${ }^{4}$ Russell R., Tokatlian J.G. From Antagonistic Autonomy to Relational Autonomy: A Theoretical Reflection from the Southern Cone. Latin American Politics. 2003. № 45. P. 1-24.
} 
мітингувальники вимагали проведення прямих президентських виборів, військовий режим вирішив віддати владу демократичним силам. Першим невійськовим президентом за 21 рік військового режиму став губернатор штату Мінас-Жерайс, Танкреду Невіс, який був висуванцем від Партії ліберального фронту та Партії бразильського демократичного руху. I вже 15 січня 1985 р. його кандидатура на посаду президента країни була підтримана колегією виборців. Танкреду Невіс став першим цивільним президентом Бразилії, будучи кандидатом від опозиційних сил, а його обрання остаточно поклало край режиму військової диктатури. Однак Невіс не встиг стати до виконання своїх обов'язків, адже напередодні своєї інавгурації його було шпиталізовано і 15 січня 1985 р. замість нього присягу склав його віцепрезидент Жозе Сарні. Останній був представником партії бразильського демократичного руху і соратником Невіса по опозиційному блоку, що дозволило йому обійняти посаду віце-президента5. Через два тижні Невіс помер і Сарні почав виконувати обов'язки президента країни.

Міжнародний контекст за президентства Сарні періоду 1985 - початку 1990-х років був відзначений агонією холодної війни. У роки його правління починає зароджуватись концепція автономії «через участь» та автономії «через диверсифікацію», які будуть продовжені його наступниками. Період Жозе Сарні був, по суті, перехідним періодом, в якому економічні труднощі країни, внутрішня політика та залежність від США не давали можливості доцільно формувати власну зовнішню політикуб.

У той самий час позиція Міністерства закордонних справ не сприяла зближенню із США. Річ у тім, що за президентства Сарні, Міністерство закордонних справ очолювали по черзі два міністри, обидва з чіткими позиціями щодо ролі Бразилії на міжнародній арені. 3 подачі першого міністра закордонних справ уряду Сарні Олави Сетубала було покладено кінець політиці «відповідального прагматизму». Олаву Сетубал зазначав, що потрібно враховувати економічну ситуацію при диверсифікації зовнішніх зв'язків. А його наступник - міністр Абреу Содре, навпаки відхилився від цієї позиції та почав формувати власний підхід, який був спрямований на поліпшення позицій Бразилії у регіоні. У такий спосіб він мав на меті відновити дипломатичні відносини з Кубою, зміцнити співпрацю між Бразилією й Аргентиною, а також розвинути відносини з Уругваєм. Зближення Бразилії й Аргентини викликало негативну реакцію з боку США, які не підтримували зближення двох основних держав Південної Америки. Така поведінка США призвела до пошуку Бразилією нових партнерів в інших регіонах, зокрема було розпочато відносини з Китаєм і СРСР, окрім цього міністр Содре також прагнув розвивати відносини з африканськими країнами та Близьким Сходом, аби розширити кругозір власної дипломатії.

Так, фактично у кінці президентства Сарні, бразильська зовнішня політика ще дотримувалась старих принципів ведення зовнішньої політики, але мала певні зміни, які були обумовлені міжнародним тиском і зміною своєї міжнародної позиції. Політична криза й економічна політика, які склались у Бразилії, викликали кризу перехідного періоду, на яку припадають уряди наступних президентів: Коллора ді Меллу (1990-1992) й Ітамара Франку (1992-1995). У цей період відбулися глибокі

\footnotetext{
${ }^{5}$ Roett R. The New Brazil. Washington, DC: Brookings Institution Press, 2010. 178 p.

6 Lima M.R.S. Instituições democráticas e política exterior. Contexto Internacional. 2000. Vol. 22, № 2. P. 265-303.

7 Sarney J. Brazil: A President's Story. Foreign Affairs. 1986. №65 (1). P.101-117. DOI: http://dx.doi.org/10.2307/20042864
} 
зміни у міжнародній політиці, а саме закінчення холодної війни, а також регіоналізація, що створила нові умови для консолідації великих регіональних держав Півдня8. Початок перехідного періоду припадає на президенство Фернандо Коллора ді Меллу, який був представником Партії національної реконструкції (нині - Робітнича партія Бразилії), від якої він висувався на посаду президента. На виборах у 1989 р. Коллор здобув перемогу над соратником зі своєї партії Луїсом да Сілвою.

Президент Коллор вирізнявся з поміж інших популізмом, співпрацею з великими телевізійними компаніями Бразилії, такими як Globo, які у певній мірі й допомогли йому здобути перемогу на виборах. 3 початком свого президентського терміну Коллор мав намір визначити нову зовнішню політику для Бразилії. У своїй передвиборчій програмі майбутній президент виступав за ідеї модернізації країни та розробку власної зовнішньополітичної концепції, аби Бразилія знайшла собі місце серед країн «першого світу»9.

Уряд Коллора ді Меллу мав чітко визначені фази зовнішньої політики. Спочатку його уряд дистанціювався від зовнішньої політики, започаткованої президентом Гейзелем, а потім мав на меті створити власну концепцію. У Бразилії періоду президентства Коллора, відбувалися великі дебати між тими, хто виступав за активізацію відносин із США, й тих, хто виступав за реформуванням внутрішньої політики відповідно до основних принципів, світової політики з метою адаптувати ії до міжнародних обставин. У цьому сенсі, на відміну від попереднього періоду, зовнішня політика Бразилії мала свої точки дотику у відносинах із США. Ці точки деякі автори називають «ілюзією Коллора» щодо Північної Америки 10.

Та все ж внутрішній контекст вимагав від уряду Коллора реформ, які торкнулись і МЗС. Президент розпочав і розвинув реформу зовнішнього відомства у квітні 1992 р. У першу чергу він призначив міністром закордонних справ дипломата Селсо Лафера - людину, яка прагнула розвинути більш тісні відносини між Бразилією та країнами Південного конусу. Селсо Лафер виступав за активнішу роль Бразилії на міжнародному рівні. У зв'язку з цим, важливо відзначити Конференцію ООН з навколишнього середовища та розвитку (UNCED), що відбувалась у Ріо-де-Жанейро у 1992 р., де за ініціатив Лафера, Бразилія почала відігравати активну роль у справі розв'язання глобальних проблем. Активна участь Бразилії на конференції, на думку Коллора, мала намір визначити його нову зовнішню політику для країни.

За словами бразильських науковців Херста ${ }^{11}$ та Пінейру12, зовнішня політика Коллора мала три основні цілі: 1) модернізація міжнародної програми Бразилії, інтелектуальна власність, навколишнє середовище, права людини та новітні технології; 2) створення позитивного діалогу із США; 3) послаблення бразильського перебування серед країн третього світу. Сукупність цих цілей відіграла ключову роль у досягненні успіху Коллора у відносинах з країнами Південної Америки. Та відповідно це дало можливість з ініціативи Бразилії підписати Асунсьонський договір у березні

\footnotetext{
8 Fonseca C. A política externa brasileira da democracia: 0 paradoxo da mudança na continuidade?. Relações Internacionais. 2011. № 29. P. 33-43. URL: http://www.scielo.mec.pt/pdf/ri/n29/n29a03.pdf 9 Roett R. Op. cit.

10 Brasilio S. JR. Governo Collor: o reformismo liberal e a nova orientação da política externa brasileira. Dados. 2011. Vol. 54, № 2. P. 259-288 DOI: http://dx.doi.org/10.1590/S0011-52582011000200002

11 Hirst M., Pinheiro L. A política externa do Brasil em dois tempos. Revista Brasileira de Política Internacional. 1995. Vol. 38, № 1. P. 5-23.

12 Pinheiro L. Traídos pelo desejo: um ensaio sobre a teoria e a prática da política externa brasileira contemporânea. Contexto Internacional. 2000. Vol. 22, № 2. P. 305-335.
} 
1991 р., за яким було створено МЕРКОСУР13.

Створення МЕРКОСУР було позитивними як для країни, так і для самого Коллора (це можна вважати зовнішньополітичним успіхом президента з точки зору торгівельної політики, та позиціонування себе, як регіонального лідера Південної Америки).

У той самий час уряд Коллора дав зрозуміти, що за винятком сусідів по Південному конусу, нові пріоритети у зовнішній політиці будуть засновані і на відносинах 3 розвиненими країнами. У взаємозалежному світі, який проходить через глибокі трансформації, жодна країна не захищена від ризиків, що існують у міжнародних відносинах, а також не може відмовитися від широких можливостей співпраці, що вони пропонують ${ }^{14}$.

Проте термін перебування Коллора на посаді президента Бразилії був нетривалим - його було звинувачено у корупції. На слуханнях у Конгресі 26 серпня 1992 р. було опубліковано доповідь, де було надано докази, які свідчили про причетності його до корупції. Після цього 29 вересня 1992 р. нижньою палатою Конгресу було розпочато процес імпічменту. Під час голосування у Конгресі за відставку проголосував 441 голос, проти виступили 38, у результаті президент Фернанд Коллор ді Меллу був усунутий с посади.

Після реалізації імпічменту обов'язки президента з вересня по грудень 1992 р. виконував віце-президент Ітамар Франку, а вже з 29 грудня 1992 р. він вже був перепризначений на посаду президента країни, коли президент Коллор перед початком голосування у Конгресі подав у відставку 15.

Ітамар був представником Партії національної реконструкції та напарником Коллора на виборах, це й дало можливість йому обійняти посаду віце-президента. За короткий термін свого президентства Ітамар Франко показав відмінність від свого попередника, хоча його уряд і характеризувався, як просте продовження політики уряду Коллора. Його президенство також зумовлене великими труднощами та нестабільністю всередині країни. Уряд Ітамара Франко успадкував неспокійний внутрішній сценарій, а зовнішня політична програма опинилася під тиском США, які бажали посилення ліберальних економічних реформ у країні. На відміну від інших держав, Бразилія виділялася через свою затримку у процесі стабілізації валют та економічних реформ, а також відсутністю інтересу до переговорів щодо створення Зони вільної торгівлі в Америці16.

Через невідкладність внутрішніх проблем президент Ітамар Франко делегував формулювання зовнішньої політики майже повністю Міністерству закордонних справ, цим самим він одразу дав зрозуміти своїм критикам, що він не схожий на свого попередника. Ключовим у роботі уряду Ітамара Франко було призначення міністром закордонних справ Фернандо Енріке Кардозу, соціолога зі штату Сан-Паулу та представника від соціал-демократичної партії Бразилії. Це призначення дозволило Ітамару Франко менше використовувати президентські повноваження у здійснення закордонних справ. У короткий термін, Кардозу поглибив зовнішню політику та ви-

\footnotetext{
13 МЕРКОСУР - економічний союз держав у Південній Америці, до якого входять Аргентина, Бразилія, Парагвай, Уругвай і Венесуела, як асоційовані члени - Чилі, Болівія, Перу, Колумбія й Еквадор.

${ }^{14}$ Brasilio S. JR. Op. cit.

15 Partido da reconstrução nacional. URL: http://www.fgv.br/Cpdoc/Acervo/dicionarios/verbetetematico/partido-da-reconstrucao-nacional-prn

16 Зона вільної торгівлі в Америці - угода про усунення, або зменшення торговельних бар'єрів серед усіх країн Північної та Південної Америки, за винятком Куби.
} 
вів на новий рівень пріоритети сформовані ще за часів Селсо Лафера ${ }^{17}$. Бразильський міністр визнав США головним торговельним партнером, зауважуючи, що відносини між країнами залежать винятково від динамічності просування експорту на американський ринок. У своєму короткочасному перебуванні в якості міністра Кардозу вже бачив необхідність у побудові «нової зовнішньої політики»18.

Але бажання президента Франко призначити Кардозу міністром фінансів не дало можливість останньому реалізувати свої плани у побудові нової зовнішньої політики країни. Наступник Кардозу на посту міністра МЗС Селсо Аморім почав використовувати власну концепцію, яка отримала назву «розумна автономія» або ще їі називають «автономія через участь». Завдання даної концепції було наступним: розширення участі Бразилії на міжнародній арені та посилення впливу в регіоні й утримання у ньому пальми першості.

Сам міністр Аморім зазначав, що міжнародне включення Бразилії до світової спільноти повинно відбуватися через Раду Безпеки ООН. Цими заявами він намагався сформувати певну зовнішньополітичну стратегію країни на майбутнє, виступаючи за розширення РБ ООН. Щодо позиції президента Франко, то той, у свою чергу, підтримував позицію свого міністра, заперечуючи принципи, які були прийняті його попередниками.

Отже, підсумовуючи вищесказане, нам вдалося дійти до наступних висновків. Зовнішня політика Бразилії часів демократизації пройшла тяжкий шлях невизначеності та формувалася у складних умовах. Зовнішній політиці Бразилії від часів Жозе Сарні до Ітамара Франко вдалося сформувати свою власну концепцію зовнішньої політики і тим самим створити власні пріоритети та цілі. Тому можна зауважити, що бразильська зовнішня політика часів Сарні ще дотримувалася старих принципів, маючи певні успіхи у новій політиці, але так і не створивши самостійної позиції, призвела до політичної й економічної кризи, що склалася у Бразилії. Через це у період кризи відбувалися ті бажані зміни, яких потребувала зовнішня політика. Курс Коллора де Меллу та Ітамара Франку дав початок формуванню основних пріоритетів бразильської зовнішньої політики: створити МЕРКОСУР, диверсифікувати відносини з іншими країнами регіону та світу, маючи ціль увійти до Ради Безпеки ООН.

\section{REFERENCES}

Brasilio, S. JR. (2011). Governo Collor: o reformismo liberal e a nova orientação da política externa brasileira. Dados, 54 (2), 259-288. DOI: http://dx.doi.org/10.1590/S0011-52582011000200002 [in Portuguese].

Cardoso, F.H. (1993). Política externa: fatos e perspectivas. Política Externa, 1 (2), 3-10 [in Portuguese].

Fausto, B. (1994). História do Brasil. Vol. 1. São Paulo: Edusp [in Portuguese].

Fonseca, C. (2011). A política externa brasileira da democracia: O paradoxo da mudança na continuidade? Relações Internacionais, 29, 33-43 [in Portuguese].

Hirst, M. \& Pinheiro, L. (1995). A política externa do Brasil em dois tempos. Revista Brasileira de Política Internacional, vol. 38, 1, 5-23 [in Portuguese].

Lima, M.R.S. (2000). Instituições democráticas e política exterior. Contexto Internacional, 22 (2), 265303 [in Portuguese].

Pinheiro, L. (2000). Traídos pelo desejo: um ensaio sobre a teoria e a prática da política externa brasileira contemporânea. Contexto Internacional, 22, (2), 305-335 [in Portuguese].

Roett, R. (2010). The New Brazil. Washington, DC: Brookings Institution Press [in English].

Russell, R. \& Tokatlian, J.G. (2003). From Antagonistic Autonomy to Relational Autonomy: A

${ }^{17}$ Cardoso F.H. Política externa: fatos e perspectivas. Política Externa. 1993. № 1. T. 2. P. 3-10.

18 Vigevani T., Oliveira M.F., Cintra R. Política externa no período FHC: a busca de autonomia pela integração. Tempo Social. 2003. Vol. 15, № 2. P. 31-61. 
Theoretical Reflection from the Southern Cone. Latin American Politics and Society, 45 (1), 1-24. DOI: http://dx.doi.org/10.1111/j.1548-2456.2003.tb00230.x [in English].

Saraiva, M.G. (2010). A diplomacia brasileira e as visões sobre a inserção externa do Brasil: institucionalismo pragmático $x$ autonomistas. Boletín Elcano (123), 9. Retrieved from: http://biblioteca.ribei.org/1830/ [in Portuguese].

Sarney, J. (1986). Brazil: A President's Story. Foreign Affairs, 65 (1), 101-117. DOI: http://dx.doi.org/10.2307/20042864 [in English].

Vigevani, T., Cepaluni, G. \& Schmitter, Ph.C. (2009). Brazilian Foreign Policy in Changing Times: The Quest for Autonomy from Sarney to Lula. Maryland: Lexington Books [in English].

Vizentini, P. (2003). A política externa brasileira em transição: do desenvolvimento ao neoliberalismo. In Martins, Estevão C. De Rezende (org.). Relações Internacionais. Visões do Brasil e da América Latina. Brasília: IBRI [in Portuguese].

Vigevani, T., Oliveira, M.F. \& Cintra, R. (2003). Política externa no período FHC: a busca de autonomia pela integração. Tempo Social, 15 (2), 31-61. DOI: http://dx.doi.org/10.1590/S010320702003000200003 [in Portuguese].

\section{Myroslav Zhoga}

(The State Institution «Institute of World History of the National Academy of Sciences of Ukraine», Kyiv, Ukraine)

ORCID: https://orcid.org/0000-0002-4049-9411

\section{Formation of Brazil's Foreign Policy from 1985 to 1995: from José Sarney to Itamar Franco}

The attempts to analyze Brazil's foreign policy from 1985 to 1995 is made in this paper. Particular attention is paid to the place of the Presidents of Brazil and their influence on the development of the country's foreign policy. The factors that had influenced the forming of Brazil's foreign policy in relations with the US, the EU, and Latin American countries are analyzed and the nature of their changes during the specified period is determined. While in the second half of the 1980s, Brazil focused solely on the United States and was dependent on its position, by the mid-1990s, it began to renounce the influence of Washington pursuing practically independent home and foreign policy. As a result, the country started to develop its own Latin American policy, established, together with Argentina and other Southern Cone countries, the MERCOSUR. Besides, after the end of the Cold War, Brazil began to develop alternative foreign policy directions, getting closer to the European Union, China, and the developing countries. In doing so, Brazil is positioning itself as the leader of South America and a full-fledged world player.

Keywords: Brazil, foreign policy, Latin America, autonomy, MERCOSUR 